\title{
Article \\ A Nickel Coated Copper Substrate as a Hydrogen Evolution Catalyst
}

\author{
Poshan Kumar Reddy Kuppam ${ }^{1}$, K. M. M. D. K. Kimbulapitiya ${ }^{2,3}$, Srikanth Vuppala ${ }^{4, *(D)}$, Kuangye Wang ${ }^{3}$, \\ G. Phaneendra Reddy ${ }^{5}$, Krishna P. Pande ${ }^{6, *}$, Po-Tsung Lee ${ }^{1, *}$ and Yun-Lun Chueh ${ }^{3}$
}

1 UST-IPP, College of Electrical and Computer Engineering, National Yang Ming Chiao Tung University, Hsinchu 30010, Taiwan; poshank.ee04@nycu.edu.tw

2 Department of Physics, National Sun Yat-sen University, Kaohsiung 80424, Taiwan; supunbcc@gmail.com

3 Department of Materials Science and Engineering, National Tsing Hua University, Hsinchu 30010, Taiwan; wangkuagye911101@gmail.com (K.W.); ylchueh@mx.nthu.edu.tw (Y.-L.C.)

4 Department of Civil and Environmental Engineering, Politecnico di Milano, Piazza Leonardo da Vinci, 32, 20133 Milan, Italy

5 Department of Physics, Sri Venkateswara Vedic University, Tirupati 517 502, India; phaneendra369@gmail.com

6 International College of Semiconductor Technology, National Yang Ming Chiao Tung University, Hsinchu 30010, Taiwan

* Correspondence: srikanth.vuppala@uniroma1.it (S.V.); kppande@nctu.edu.tw (K.P.P.); potsung@mail.nctu.edu.tw (P.-T.L.)

check for updates

Citation: Kuppam, P.K.R.;

Kimbulapitiya, K.M.M.D.K.; Vuppala,

S.; Wang, K.; Reddy, G.P.; Pande, K.P.;

Lee, P.-T.; Chueh, Y.-L. A Nickel

Coated Copper Substrate as a

Hydrogen Evolution Catalyst.

Catalysts 2022, 12, 58. https://

doi.org/10.3390/catal12010058

Academic Editors: Alessandro Di

Michele and Carlo Pirola

Received: 30 November 2021

Accepted: 31 December 2021

Published: 5 January 2022

Publisher's Note: MDPI stays neutral with regard to jurisdictional claims in published maps and institutional affiliations.

Copyright: () 2022 by the authors Licensee MDPI, Basel, Switzerland. This article is an open access article distributed under the terms and conditions of the Creative Commons Attribution (CC BY) license (https:// creativecommons.org/licenses/by/ $4.0 /)$.

\begin{abstract}
Replacing precious metals with low-cost metals is the best solution for large scale production. Copper is known for its excellent conductivity and thermal management applications. When it comes to hydrogen evolution reaction, it is highly unstable, especially in $\mathrm{KOH}$ solution. In this paper, we approached a simple method to reduce corrosion and improve the performance by depositing nickel-molybdenum oxide and nickel on copper substrates and the achieved tafel slopes of $115 \mathrm{mV} / \mathrm{dec}$ and $117 \mathrm{mV} / \mathrm{dec}$ at $10 \mathrm{~mA} / \mathrm{cm}^{2}$. While at first, molybdenum oxide coated samples showed better performance after 100 cycles of stability tests, the onset potential rapidly changed. $\mathrm{Cu}-\mathrm{Ni}$, which was deposited using the electron gun evaporation (e-gun), has shown better performance with $0.28 \mathrm{~V}$ at $10 \mathrm{~mA} / \mathrm{cm}^{2}$ and led to stability after 100 cycles. Our results show that when copper is alloyed with nickel, it acts as a promising hydrogen evolution reaction (HER) catalyst.
\end{abstract}

Keywords: copper; hydrogen evolution; nickel; coating

\section{Introduction}

Water electrolysis is one of the best alternative methods to solve future energy storage problems in green industries [1]. Over the past decade, many alternative materials for hydrogen evolution reaction (HER) have been proposed to replace platinum and gold metals, due to scarcity and high-cost for large scale production. Among the earth-abundant and inexpensive oxides [2,3], sulphides [4,5], selenides [6,7], phosphide [8], carbide-based [9,10] semiconductors have been identified for stable HER. To verify the electrocatalytic performance, a good metal is preferred. Among these, transition metals have raised great interest, due to their vast availability in nature [11]. Moreover, durability-wise, these metals showed better performance in the case of HER.

Copper $(\mathrm{Cu})$ substrate is known to be highly conductive and the best thermal management metal in transition metals [12], but in the case of electrolysis, it is unstable in solution, due to the formation of oxide on the surface [13]. However, researchers try to resolve this problem by alloying with other transition metals for oxygen evolution reactions (OER) and HER electrocatalytic activity [14-16]. Especially when copper has alloyed with nickel, in most cases it has been shown to be more stable and higher electrocatalytic activity, when compared to nickel electrodes $[14,17]$. This may be due to the synergistic effect of 
the change in nickel composition on copper, which can enhance catalytic activity [18,19]. Similar reports have been reported when nickel is alloyed with molybdenum (Mo) metal, which enhances the performance of HER [20-28]. In general, nickel is known to have the best HER, due to hydrogen adsorption energy on its surface, but it suffers from lower resistance during electrolysis. This can be reduced by alloying with other transition metals [29]. In this case, alloying with molybdenum or molybdenum oxide is one of the best choices, due to its higher resistance and more surface area [30,31]. When these ternary $\mathrm{Cu}-\mathrm{Ni}-\mathrm{MoO}_{3}$ composite materials are used for HER, it leads to better performance, due to mostly unpaired d-electrons in metals, which can donate electrons and adsorb hydrogen atoms, which is more advantageous for electrocatalytic activity [28].

The preceding reports inspired us to investigate the influence of $\mathrm{Ni}$ and $\mathrm{Ni}-\mathrm{MoO}_{3}$ on copper foil, and we present a simple method to reduce fabrication costs by using electron gun evaporation (e-gun), and the prepared samples have shown higher catalytic activity for HER application than OER. In both cases, initially, the $\mathrm{Ni}-\mathrm{MoO}_{3}$ has shown tremendous performance, while in the long run (100 cycles), $\mathrm{Cu}-\mathrm{Ni}$ has shown better performance with $0.28 \mathrm{~V}$ and leads to stability. Our results show that when copper is alloyed with nickel, it acts as a promising HER catalyst and can be applied for electrolysis in large scale production.

\section{Results and Discussion}

Figure 1 shows the $\mathrm{X}$-ray diffraction patterns of the $\mathrm{Cu} / \mathrm{Ni}$ bi-layer substrate and $\mathrm{Cu} / \mathrm{Ni} / \mathrm{MoO}_{3}$ stack. The XRD patterns revealed the polycrystalline nature for all sulfurized films. From the XRD pattern, it is perceived that all the profile peaks were positioned at 43.33, 50.46, and 74.15 degrees and were indexed with Miller indices (1 111$),\left(\begin{array}{lll}2 & 0 & 0\end{array}\right)$, and (2 20 ). All these XRD peaks were well matched with JCPDS: 003-1005 cubic crystal structure of $\mathrm{Cu}$. The lattice parameters $\mathrm{a}=\mathrm{b}=\mathrm{c}=3.6077(\AA), \alpha=\beta=\gamma=90^{\circ}$. The average crystallite size was calculated by using Debye-Scherrer's formula, and it was found to be 51.5 and $65 \mathrm{~nm}$ for $\mathrm{Cu} / \mathrm{Ni}$ substrate and $\mathrm{Cu} / \mathrm{Ni}(100 \mathrm{~nm}) / \mathrm{MoO}_{3}(50 \mathrm{~nm})$ stack, respectively. From $\mathrm{XRD}$ patterns, the $\mathrm{Cu} / \mathrm{Ni} / \mathrm{MoO}_{3}$ stack showed a wide peak at 89.20 degrees, which corresponded to the (361) plane of the orthorhombic structure of $\mathrm{MoO}_{3}$ and closely matched with the JCPDS card num: 005-0507.

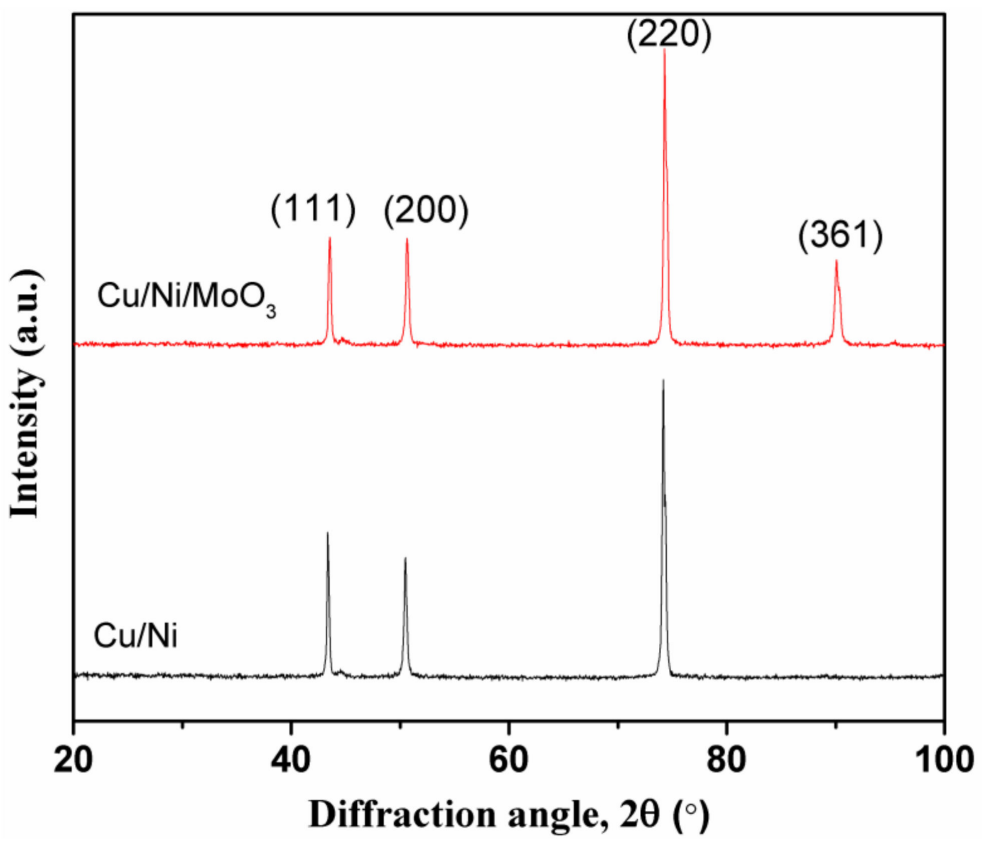

Figure 1. XRD peaks of $\mathrm{Cu} / \mathrm{Ni}$ and $\mathrm{Cu} / \mathrm{Ni} / \mathrm{MoO}_{3}$ stack. 
The vibrational Raman spectrum of $\mathrm{Cu} / \mathrm{Ni} / \mathrm{MoO}_{3}$ stack is shown in Figure 2. This can be clearly observed from the $\mathrm{Cu} / \mathrm{Ni}$ Raman spectrum, as it consists of the only single strong absorption peak, at $933 \mathrm{~cm}^{-1}$ and it belongs to the $\mathrm{B} 1 \mathrm{~g}$ symmetry of $\mathrm{vO}=$ Mo stretching vibrational modes [32]. No more absorption peaks were observed in the sample, due to $\mathrm{Cu}$ and $\mathrm{Ni}$. The Raman spectrum contracts the XRD spectra, in XRD studies Cu was only presented but remaining coated elements were not identified, but in Raman studies $\mathrm{Cu}$ and $\mathrm{Ni}$ were not detected. This is due to the $\mathrm{Cu}$ and $\mathrm{Ni}$ being lower layers and $\mathrm{MoO}_{3}$ is the upper layer of the thin film.

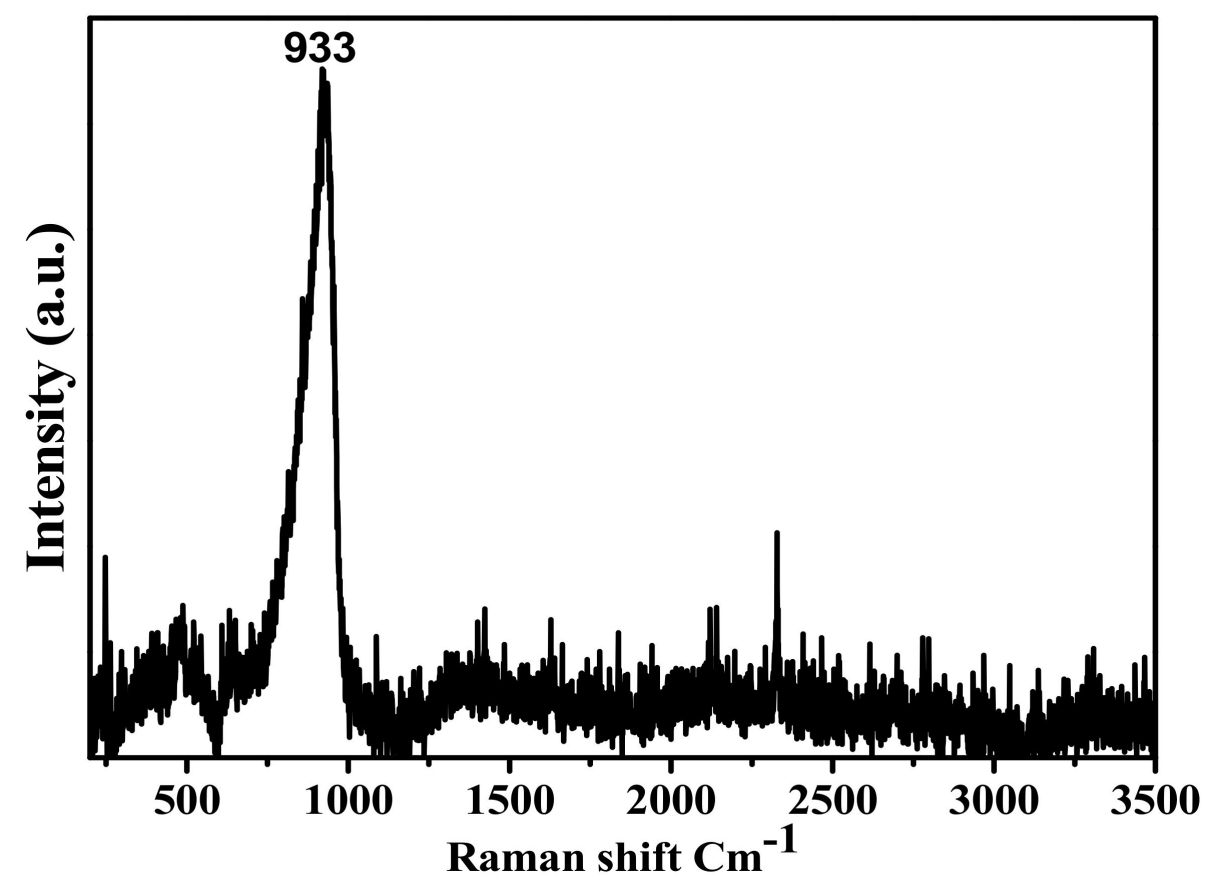

Figure 2. Raman analysis of $\mathrm{MoO}_{3}$ thin film.

The chemical composition and valance start of $\mathrm{Ni}-\mathrm{MoO}_{3}$ films on $\mathrm{Cu}$ substrates were analyzed using X-ray photoelectron spectroscopy (XPS), through this analysis analyzed the oxidization state of the transition metal ion. The shift of the binding energy, due to relative surface charging, was corrected using the $\mathrm{C} 1 \mathrm{~s}$ level at $284.8 \mathrm{eV}$ as an internal standard (Figure 3a). The XPS spectra of $\mathrm{Cu}, \mathrm{Ni}, \mathrm{Mo}$, and $\mathrm{O}$ elements in the films are shown in Figure $3 \mathrm{~b}-\mathrm{e}$. Figure $3 \mathrm{~b}$ shows the $\mathrm{Cu} 2 \mathrm{p} 3 / 2$ and $\mathrm{Cu} 2 \mathrm{p} 1 / 2$ binding energy peaks at $932.7 \mathrm{eV}$ and $953.45 \mathrm{eV}$ [33]. There is no shoulder peak observed in the spectrum, which indicates, $\mathrm{Cu}$ is not bonding with oxygen. In the Ni 2p spectrum, (Figure 3c) the peaks at $855.5 \mathrm{eV}$ and $872.1 \mathrm{eV}$ are assigned to $\mathrm{Ni} 2 \mathrm{p}_{3 / 2}$, and $\mathrm{Ni} 2 \mathrm{p}_{1 / 2}$ binding energy levels indicate $\mathrm{Ni}^{2+}$. The distinct peaks at 232.68 and $235.88 \mathrm{eV}$ are assigned to $3 \mathrm{~d}_{5 / 2}$ and $3 \mathrm{~d}_{3 / 2}$ of $\mathrm{Mo}^{6+}$ (Figure $3 \mathrm{~d}$ ), the spectra of $\mathrm{O} 1 \mathrm{~s}$ region (Figure $3 \mathrm{e}$ ) shows a peak at $531.2 \mathrm{eV}$, corresponding to the lattice oxide ions on the surface. In order to check whether the formation oxide takes place on $\mathrm{Ni}$ thin film, we check with EDS in Figure 5a and find no evidence of oxidation on nickel film.

Microstructural analysis of $\mathrm{Cu}, \mathrm{Cu}-\mathrm{Ni}$ bi-layer, and $\mathrm{Cu} / \mathrm{Ni} / \mathrm{MoO}_{3}$ stacks of prepared layers were analyzed using SEM analysis. Figure 4a,c,e shows a slightly smooth surface view of $\mathrm{Cu}, \mathrm{Cu}-\mathrm{Ni}$, and $\mathrm{Cu} / \mathrm{Ni} / \mathrm{MoO}_{3}$. When this is used for HER, irregularly shaped grains are observed on the substrate surface, due to corrosion, especially in the case of $\mathrm{Cu}$, where it is higher, as shown in Figure $4 \mathrm{~b}$. In Figure $4 d$, the $\mathrm{Cu} / \mathrm{Ni}$ stack has a lower impact than $\mathrm{Cu}$. While the $\mathrm{MoO}_{3}$ on the surface of the $\mathrm{Cu}-\mathrm{Ni}$ substrate has been etched away, due to this layer in Figure 4f, the nickel suffers less damage than other substrates. SEM images clearly show the presence of $\mathrm{MoO}_{3}$ leads to less damage for the HER application. 

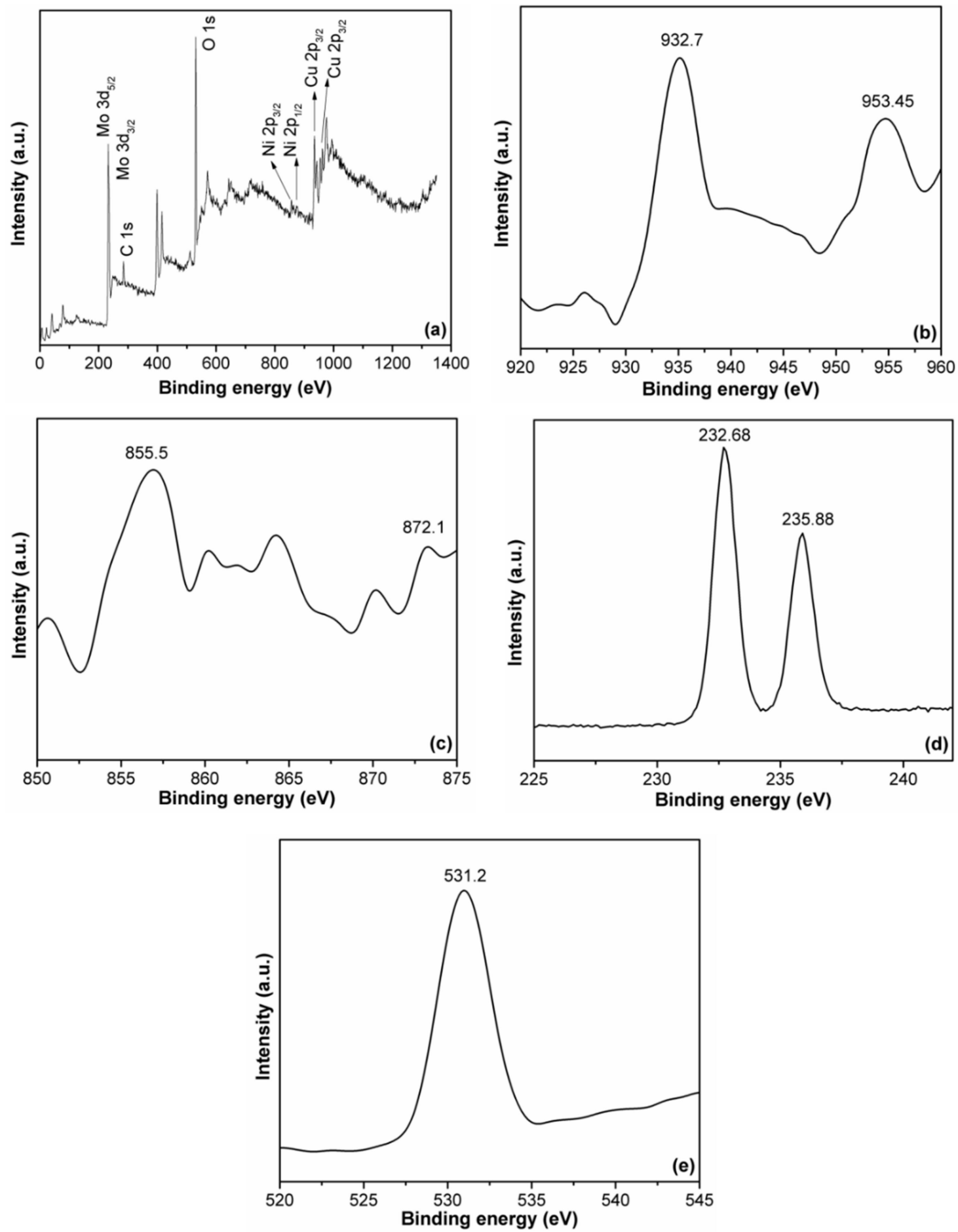

Figure 3. (a) Typical wide scan and core level (b) Cu 2p, (c) Ni 2p, (d) Mo 3d, and (e) O 1 s XPS spectra of $\mathrm{Cu} / \mathrm{Ni} / \mathrm{MoO}_{3}$ stack.

Figure 5a shows the EDS spectrum of the $\mathrm{Cu}-\mathrm{Ni}$ bi-layer, which clearly describes the presence of $\mathrm{Cu}$, Ni elements in the layer; no other peaks were observed, due to surface etching of the layer. Figure $5 \mathrm{~b}$ clearly represents the presence of $\mathrm{Cu}, \mathrm{Ni}, \mathrm{Mo}$, and Oxygen elements in the $\mathrm{Cu} / \mathrm{Ni} / \mathrm{MoO}_{3}$ stack.

In order to check OER, a standard three-electrode system with a Pt counter electrode and $\mathrm{Ag} / \mathrm{AgCl}$ reference electrodes was used with the $\mathrm{Cu}, \mathrm{Cu} / \mathrm{Ni}$, and $\mathrm{Cu} / \mathrm{Ni} / \mathrm{MoO}_{3}$ as working electrodes. All the linear sweep voltammetry (LSV) was carried out in the potential region of $0-1.75 \mathrm{~V}$ vs $\mathrm{RHE}$ at a scan rate of $5 \mathrm{mV} / \mathrm{sec}$, as shown in Figure 6. O.1 M KOH 
was used as an electrolyte solution for OER. $\mathrm{Ni}$ and $\mathrm{MoO}_{3}$ were deposited at a deposition rate of $0.2 \mathrm{~A}^{0} / \mathrm{s}$ by an e-beam evaporation system.

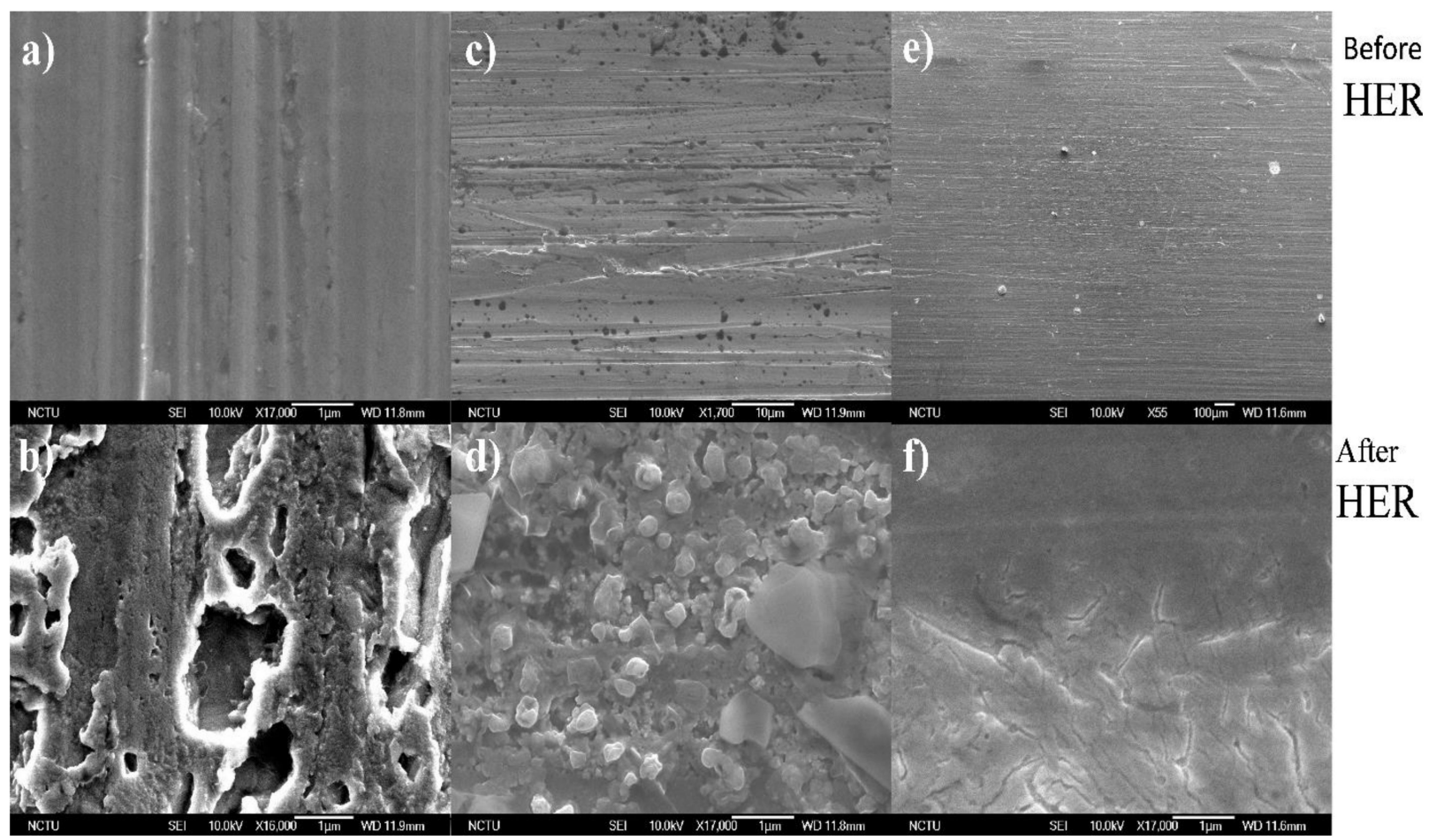

Figure 4. SEM micrographs of $\mathrm{Cu}, \mathrm{Cu}-\mathrm{Ni}$, and $\mathrm{Cu}-\mathrm{Ni}-\mathrm{MoO}_{3}(\mathbf{a}, \mathbf{c}, \mathbf{e})$, before the experiment and $(\mathbf{b}, \mathbf{d}, \mathbf{f})$ after the experiment.
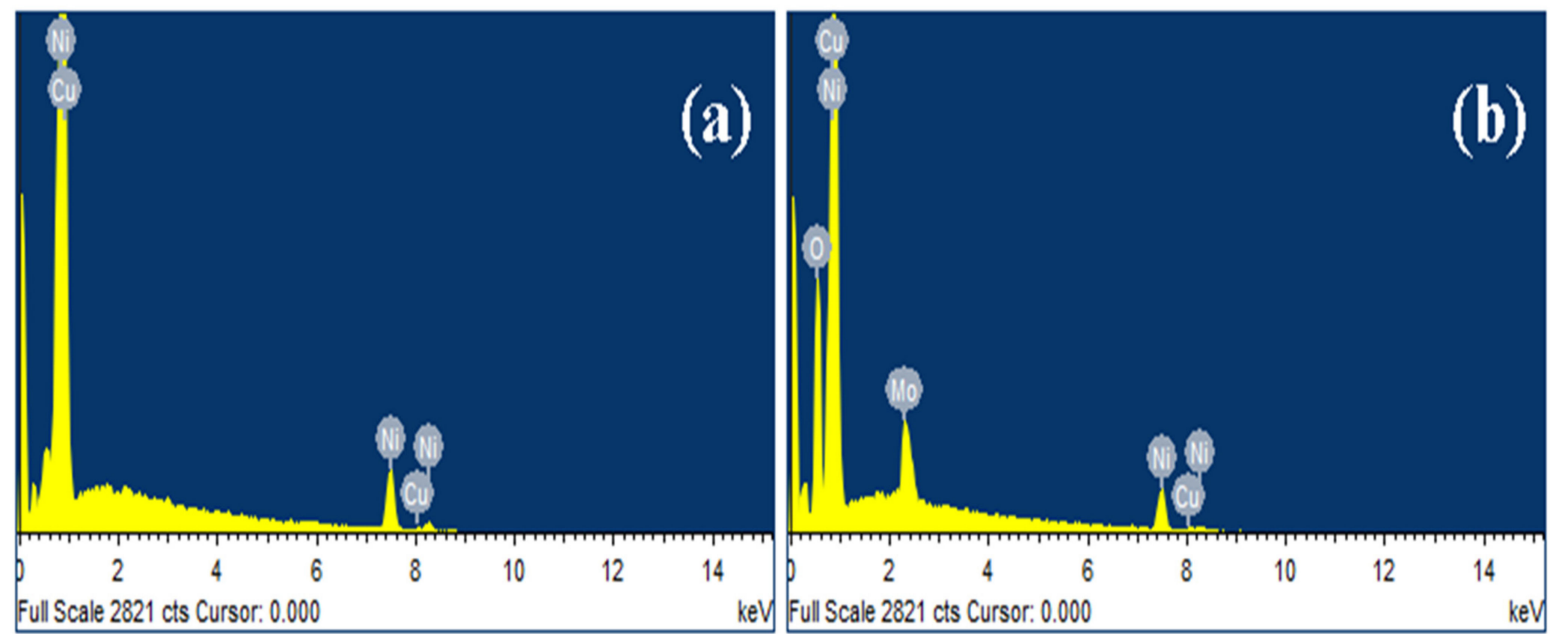

Figure 5. EDS spectra of (a) $\mathrm{Cu}-\mathrm{Ni}$ bi-layer substrate and (b) $\mathrm{Cu} / \mathrm{Ni} / \mathrm{MoO}_{3}$ stack.

The $\mathrm{Cu}-\mathrm{Ni}-\mathrm{MoO}_{3}$ showed the best performance with a potential of 1.37 followed by $\mathrm{Cu}-\mathrm{Ni}$ with $1.46 \mathrm{~V}$, as shown in Figure 6a. We comparatively check the OER Over potential of all samples at $5 \mathrm{~mA} / \mathrm{cm}^{2}$. $\mathrm{Cu}-\mathrm{Ni}-\mathrm{MoO}_{3}, \mathrm{Cu}-\mathrm{Ni}$ has shown less Tafel slope $73 \mathrm{mV}$ and $126 \mathrm{mV}$, as shown in Figure $6 \mathrm{~b}$ but, after a while, $\mathrm{Cu}-\mathrm{Ni}-\mathrm{MoO}_{3}$ was affected due to the corrosion and leads to slight stable at $1.44 \mathrm{~V}$. While $\mathrm{Cu}-\mathrm{Ni}$ is quite opposite to $\mathrm{Cu}-\mathrm{Ni}-\mathrm{MoO}_{3}$ sample at beginning it starts with $1.46 \mathrm{~V}$ after 100 cycles of stability its onset potential is improved slightly to $1.44 \mathrm{~V}$, as shown in Figure 6c. We expect that nickel, when reacting with electrolytes, may lead to form oxide known to be nickel oxide, which is effectively stable in $\mathrm{KOH}$ solution. 

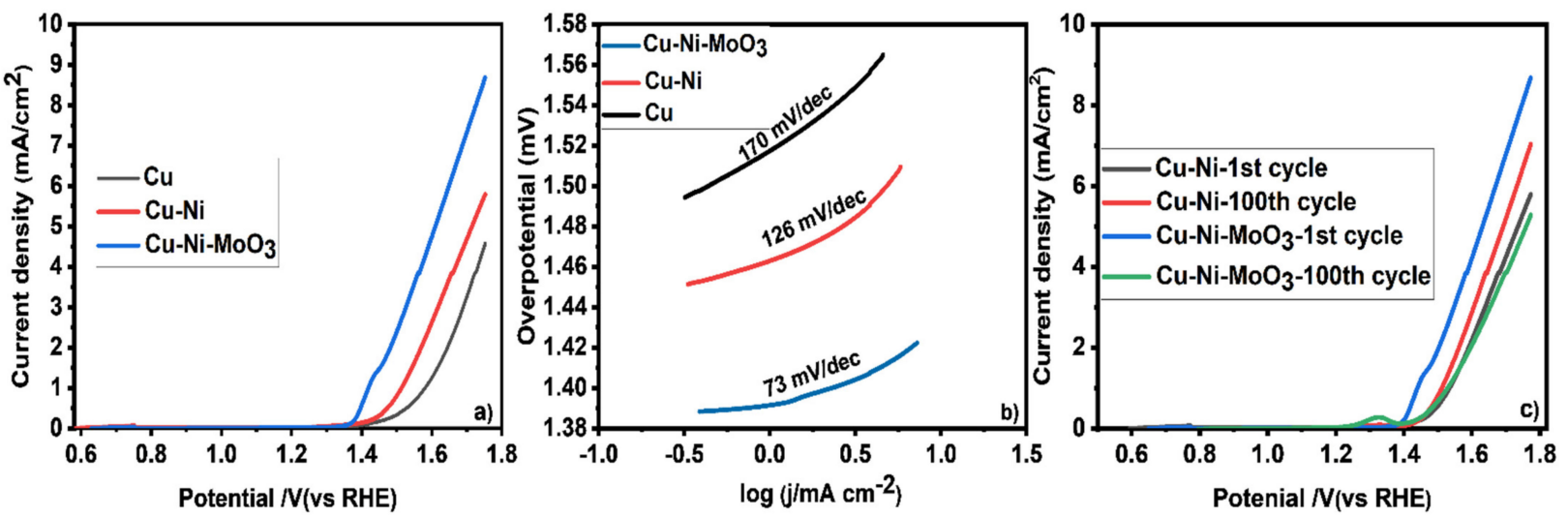

Figure 6. OER catalytic performances of three different electrodes in $0.1 \mathrm{M} \mathrm{KOH}$ electrolyte (a); Over potential of different electrodes (b); results of OER before and after 100 cycles (c).

As shown in Figure 7a Electrocatalytic results inform that $\mathrm{Cu}-\mathrm{Ni}-\mathrm{MoO}_{3}$ and $\mathrm{Cu}-\mathrm{Ni}$ are more favourable to HER. The potential at $10 \mathrm{~mA} / \mathrm{cm}^{2}$ is $0.36 \mathrm{~V}$ for $\mathrm{Cu}-\mathrm{Ni}-\mathrm{MoO}_{3}$ and 0.41 for $\mathrm{Cu}-\mathrm{Ni}$. The acquired Tafel slope values, as shown in Figure $7 \mathrm{~b}$, are almost near for both $\mathrm{Cu}-\mathrm{Ni}-\mathrm{MoO}_{3}$ and $\mathrm{Cu}-\mathrm{Ni}$ is $117 \mathrm{mV}$ and $115 \mathrm{mV}$. We notice after 100 cycles, as shown in Figure 7c. The catalytic activity has been gradually increased in both potential values $\mathrm{Cu}-\mathrm{Ni}-\mathrm{MoO}_{3}, \mathrm{Cu}-\mathrm{Ni}$ cases with $0.31 \mathrm{~V}$ and $0.28 \mathrm{~V}$. Normally in $\mathrm{MoO}_{3}$ oxygen vacancies (Vo) create Mo dangling bonds (DB), these generate defects near to conduction band [34,35]. The existence of $\mathrm{DB}$ in oxygen inefficient molybdenum oxides makes them highly responsive for HER [36]. Many theoretical reports suggest that surface defects like Vo can lead to emerging of gap states that act as shallow donors in metal oxides which may increase free charge carrier concentration [37,38]. As we deposited the $\mathrm{MoO}_{3}$, using the e-gun, the probability of formation the of Vo and surface defects was higher; this may be one of the reasons for initial higher performance. As e-gun deposited samples especially in the case of metal oxides are highly corrosive due to the amorphous nature and also lack of strong bonding between $\mathrm{Ni}-\mathrm{MoO}_{3}$ interface. In order to check this, we perform electrical characterization and notice there is no response from $\mathrm{Cu}-\mathrm{Ni}-\mathrm{MoO}_{3}$ and conclude the film grown is amorphous. The electrical characterization of the $\mathrm{Cu}$ and $\mathrm{Cu} / \mathrm{Ni}$ was also performed. I-V scans taken from two different samples show the obvious Ohmic behaviour of both $\mathrm{Cu}$ and $\mathrm{Cu} / \mathrm{Ni}$ up to $100 \mathrm{mV}$. The resistance of $\mathrm{Cu}$ and $\mathrm{Cu} / \mathrm{Ni}$ was measured to be $48.5 \Omega$ and $10.0 \Omega$, respectively, indicating that the heterostructure of $\mathrm{Cu}$ and $\mathrm{Ni}$ is more conductive than pristine $\mathrm{Cu}$, as shown in Figure 8. In Table 1, we compared the results with other researchers' results.
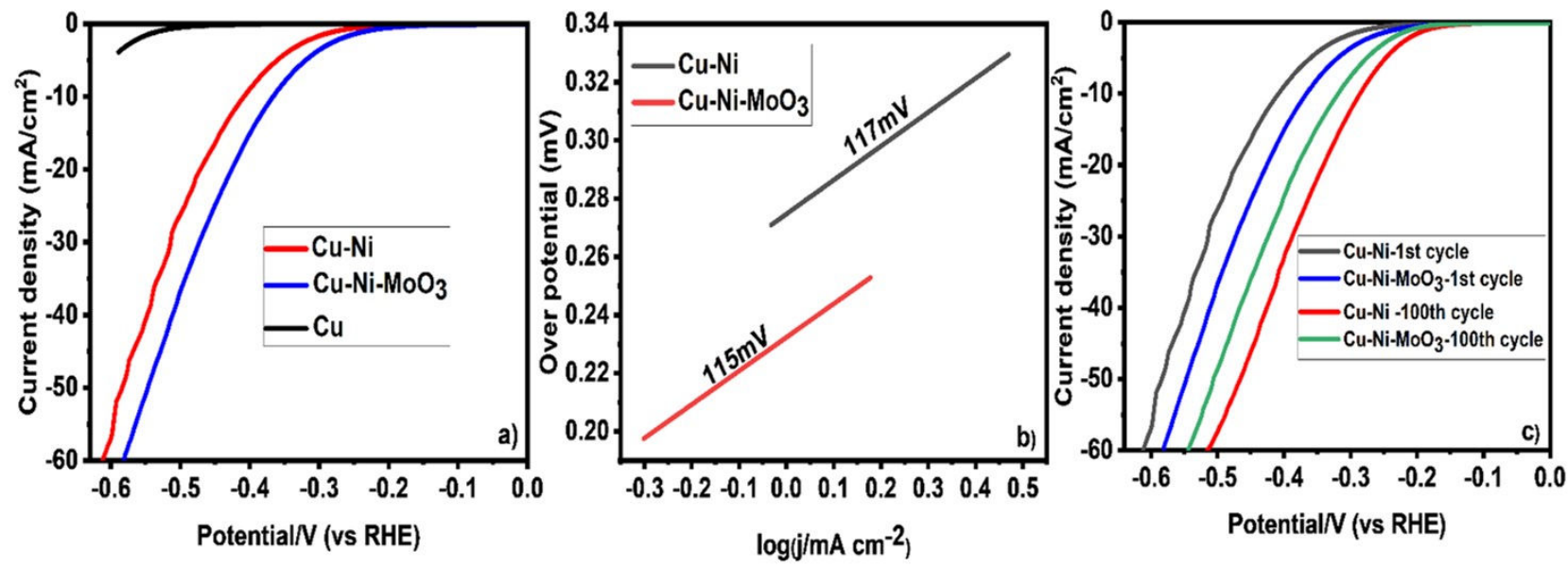

Figure 7. HER catalytic performances of three different electrodes in $0.1 \mathrm{M} \mathrm{KOH}$ electrolyte (a); Tafel plot of different electrodes (b); results of OER before and after 100 cycles (c). 


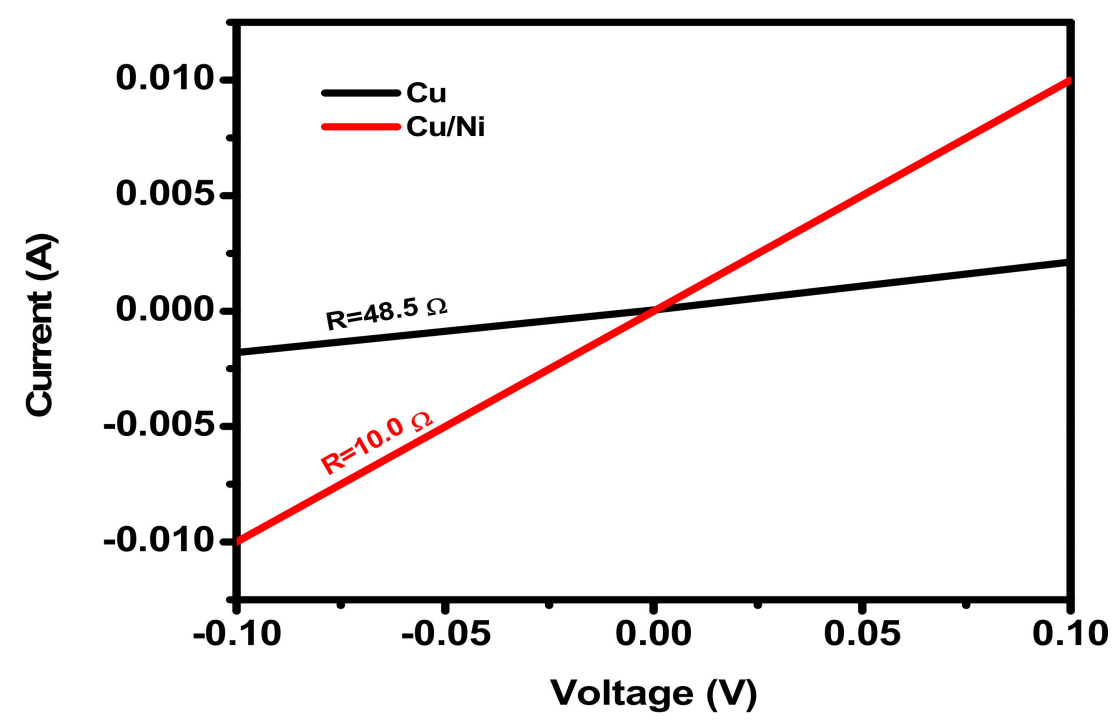

Figure 8. Electrical characterization of $\mathrm{Cu}-\mathrm{Ni}$.

Table 1. Comparison of the HER performance of $\mathrm{Cu}-\mathrm{Ni}$ with other reports.

\begin{tabular}{ccc}
\hline Catalyst & Tafel Slope (mV dec-1) & Reference \\
\hline NiSe $_{2}$ Nano sheets & 184 & {$[39]$} \\
Carbon paper/carbon tubes/Co-S & 131 & {$[40]$} \\
N, P, Co-doped graphene & 145 & {$[41]$} \\
$\mathrm{Cu} / \mathrm{Ni} / \mathrm{MoO}_{3}$ & 115 & This work \\
\hline
\end{tabular}

\section{Materials and Methods}

\subsection{Raw Materials and Preparation of Catalysts}

Experimental Method: The pure copper substrate is cleaned with acetic acid at $70{ }^{\circ} \mathrm{C}$ to remove the residuals on the surface. Nickel is first deposited on copper at $0.2 \mathrm{~A}^{0} / \mathrm{s}$ for about $100 \mathrm{~nm}$, followed by an e-gun deposit of 40-50 nm of molybdenum oxide at room temperature.

Technique: In order to deposit the nickel and molybdenum oxide, we use the ferrotec temescal FC-2800 model e-beam evaporation deposition system (e-gun), which was installed at National Tsing Hua University. We procured nickel pellets and a lump of molybdenum oxide was ordered from Gredmann Company (Taipei, Taiwan). The deposition starts at a high vacuum of $5 \times 10^{-6}$ mbar at $0.2 \mathrm{~A}^{0} / \mathrm{S}$. The thickness monitor is based on a quartz crystal oscillator connected to a deposition controller module. The quartz crystal sensor is mounted in such a manner that it is kept close to the substrate with the proper tooling factor. The deposition controller provides the final thickness of the film and also the deposition rate.

\subsection{Characterization of Composition and Structure of Catalysts}

In order to check the crystalline of prepared samples, X-ray diffraction (XRD) patterns were recorded using the AERIS diffractometer PANalytical, Model AERIS (40 KV, 7.5 mA, Almelo, the Netherlands). The average crystallite size was calculated by using DebyeScherrer's formula. The chemical states of different elements present in the films were investigated by an X-ray photoelectron spectrometer (XPS, Thermo Scientific, Model: KALPHA surface analysis, Waltham, MA, USA). The XPS spectra were recorded in the binding energy range, $0-1300 \mathrm{eV}$ using the $\mathrm{Al} \mathrm{K} \alpha$ source and calibrated using the $\mathrm{C} 1 \mathrm{~s}$ line. SEM images and energy-dispersive X-ray spectroscopy (EDS) were found using the field emission scanning electron microscope Joel JSM-6700F (Tokyo, Japan). Micro-Raman spectroscopy (Model: Lab RAM: HR800, Manufacturer: HORIBA Scientific SAS, Palaiseau, France), equipped with a $514 \mathrm{~nm}$ laser was used to examine $\mathrm{Cu}-\mathrm{Ni}-\mathrm{MoO}_{3}$. 


\subsection{Electrochemical Measurement}

Electrochemical measurements were performed in a three-electrode system using a Bio-Logic VSP potentiostat in a cylindrical cell made of Teflon with an O-ring in the bottom with a working electrode area of $0.264 \mathrm{~cm}^{2}$. The $\mathrm{Cu}, \mathrm{Cu} / \mathrm{Ni}$ and $\mathrm{Cu} / \mathrm{Ni} / \mathrm{MoO}_{3}$ samples were contacted with double-sided $\mathrm{Cu}$ tape $(3 \mathrm{M})$ as working electrodes with a platinum wire counter electrode and $\mathrm{Ag} / \mathrm{AgCl}(3 \mathrm{M} \mathrm{NaCl})$ reference electrode; $0.1 \mathrm{KOH}$ were used as the electrolyte solution for HER and OER, respectively, during the measurements. All the experiments were conducted without magnetically stirring the solution, as shown in Figure 9. All the potentials were converted to RHE, using the equation given by $\mathrm{E}_{\mathrm{RHE}}=\mathrm{E}_{\mathrm{Ag} / \mathrm{AgCl}}+0.0591 \times \mathrm{pH}+0.194$ [42], resulting in a shift of $-0.2117 \mathrm{~V}$ versus RHE. Note all potentials in linear sweep voltammetry (LSV) were collected after applying $3-5$ potential sweeps in order to avoid the redeposition of Pt on the working electrode after several cycles. LSV data was recorded at a scan rate of $5 \mathrm{mV} / \mathrm{s}$ for the first few cycles and long-term stability was assessed at an accelerated scan rate of $100 \mathrm{mV} / \mathrm{s}$ for 100 times. Cyclic voltammograms of $\mathrm{Cu} / \mathrm{Ni}$ and $\mathrm{Cu} / \mathrm{Ni} / \mathrm{MoO}_{3}$ were acquired at different scan rates of $20-200 \mathrm{mV} / \mathrm{s}$ in the voltage between $-0.2-0 \mathrm{~V}$ (vs RHE), as shown in Supplementary Data Figure S1.

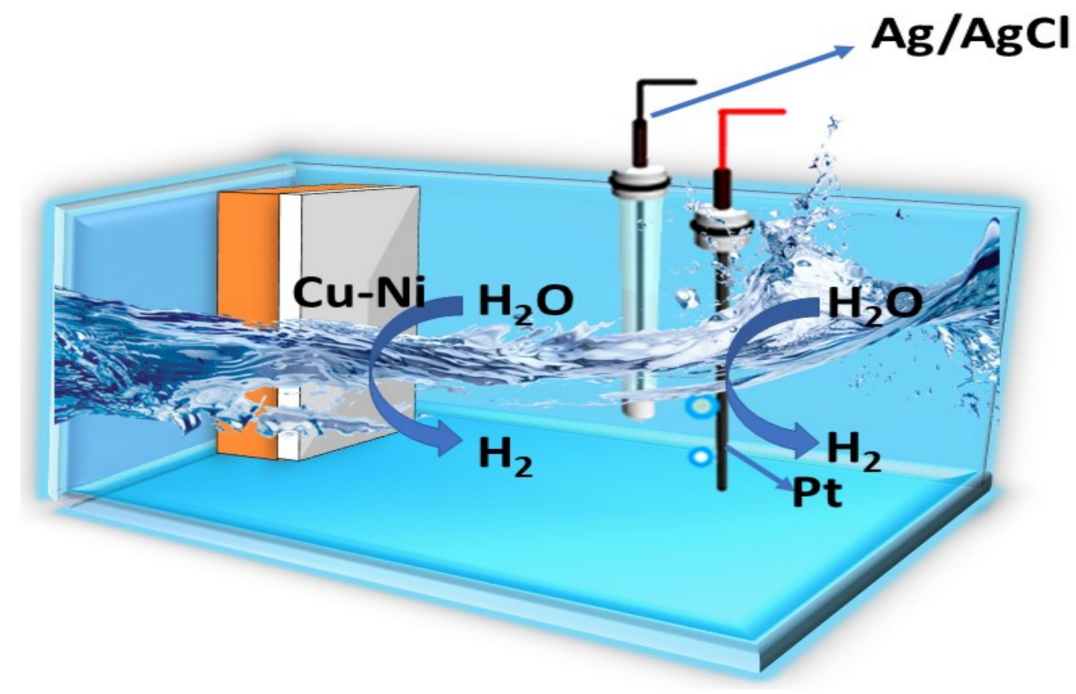

Figure 9. Schematic image of the experiment.

\section{Conclusions}

In summary, $\mathrm{XRD}$ has proved that the average crystallite size of the catalyst produced was found to be $51.5 \mathrm{~nm}$ and $65 \mathrm{~nm}$ for the $\mathrm{Cu} / \mathrm{Ni}$ substrate and $\mathrm{Cu} / \mathrm{Ni}(100 \mathrm{~nm}) / \mathrm{MoO}_{3}$ $(50 \mathrm{~nm})$ stacks, respectively; the chemical state and composition of elements was recorded using XPS and EDS. Copper substrates are highly corrosive in nature for HER and OER application. Fabrication cost has been reduced by depositing the $\mathrm{Ni}$ and $\mathrm{Ni}-\mathrm{MoO}_{3}$ thin film on $\mathrm{Cu}$, using the e-gun method, which is a cost-effective method. The prepared samples have shown higher catalytic activity for HER application than OER. The $\mathrm{Ni}-\mathrm{MoO}_{3}$ has shown tremendous performance, while in the long run (100 cycles) and $\mathrm{Cu}-\mathrm{Ni}$ have shown better performance with $0.28 \mathrm{~V}$ and leads to stability. The copper is alloyed with nickel, acts as a promising HER catalyst, and can be applied for photo-electrolysis in large scale production and reduce the cost.

Supplementary Materials: The following are available online at https:/ / www.mdpi.com/article/ 10.3390 / catal12010058/s1, Figure S1. Cyclic voltammograms at different scan rates in the potential range of $20-200 \mathrm{mV} / \mathrm{s}$ in $0.1 \mathrm{M} \mathrm{KOH}$ solution with (a) $\mathrm{Cu} / \mathrm{Ni}$ and (b) $\mathrm{Cu} / \mathrm{Ni} / \mathrm{MoO}_{3}$ (c) measured Capacitive currents. 


\begin{abstract}
Author Contributions: Conceptualization, P.K.R.K.; methodology, P.K.R.K. and K.M.M.D.K.K.; software, P.K.R.K. and G.P.R.; validation P.K.R.K. and K.M.M.D.K.K.; formal analysis, P.K.R.K., K.W., G.P.R. and K.M.M.D.K.K.; investigation, P.K.R.K. and K.M.M.D.K.K.; resources, Y.-L.C. and P.-T.L.; data curation, P.K.R.K. and K.M.M.D.K.K.; writing—original draft preparation, P.K.R.K., K.P.P. and P.T.L.; writing-review and editing, S.V., K.P.P., G.P.R. and P.-T.L.; supervision, K.P.P. and P.-T.L.; project administration, K.P.P. All authors have read and agreed to the published version of the manuscript.
\end{abstract}

Funding: This work did not receive any external funding.

Data Availability Statement: Not applicable.

Acknowledgments: K.P.K.R. thanks the National Yang Ming Chiao Tung University for providing PhD fellowship. The authors thank Srikrishna Tummala for X-ray photoelectron spectroscopy (XPS) characterization.

Conflicts of Interest: The authors declare no conflict of interest.

\title{
References
}

1. Staffell, I.; Scamman, D.; Velazquez Abad, A.; Balcombe, P.; Dodds, P.E.; Ekins, P.; Shah, N.; Ward, K.R. The role of hydrogen and fuel cells in the global energy system. Energy Environ. Sci. 2019, 12, 463-491. [CrossRef]

2. Cheng, J.; Liu, P.; Peng, T.; Liu, Q.; Chen, W.; Liu, B.; Yuan, Y.; Zhang, W.; Song, F.; Gu, J.; et al. Mechanically alloyed $\mathrm{NiTiO}$ /transition metal heterostructures: Introducing oxygen vacancies for exceptionally enhanced hydrogen evolution reaction activity. J. Mater. Chem. A 2020, 8, 14908-14914. [CrossRef]

3. Datta, R.S.; Haque, F.; Mohiuddin, M.; Carey, B.J.; Syed, N.; Zavabeti, A.; Zhang, B.; Khan, H.; Berean, K.J.; Ou, J.Z.; et al. Highly active two dimensional $\alpha-\mathrm{MoO}_{3-\mathrm{X}}$ for the electrocatalytic hydrogen evolution reaction. J. Mater. Chem. A 2017, 5, $24223-24231$. [CrossRef]

4. Kibsgaard, J.; Chen, Z.; Reinecke, B.N.; Jaramillo, T.F. Engineering the surface structure of $\mathrm{MoS}_{2}$ to preferentially expose active edge sites for electrocatalysis. Nat. Mater. 2012, 11, 963-969. [CrossRef]

5. Miao, J.; Xiao, F.X.; Bin Yang, H.; Khoo, S.Y.; Chen, J.; Fan, Z.; Hsu, Y.Y.; Ming Chen, H.; Zhang, H.; Liu, B. Hierarchical Ni-Mo-S nanosheets on carbon fiber cloth: A flexible electrode for efficient hydrogen generation in neutral electrolyte. Sci. Adv. 2015, 1, e1500259. [CrossRef]

6. Gao, M.R.; Liang, J.X.; Zheng, Y.R.; Xu, Y.F.; Jiang, J.; Gao, Q.; Li, J.; Yu, S.H. An efficient molybdenum disulfide/cobalt diselenide hybrid catalyst for electrochemical hydrogen generation. Nat. Commun. 2015, 6, 6982. [CrossRef]

7. Zhou, X.; Liu, Y.; Ju, H.; Pan, B.; Zhu, J.; Ding, T.; Wang, C.; Yang, Q. Design and Epitaxial Growth of MoSe 2 -NiSe Vertical Heteronanostructures with Electronic Modulation for Enhanced Hydrogen Evolution Reaction. Chem. Mater. 2016, 28, 1838-1846. [CrossRef]

8. Kim, M.; Anjum, M.A.R.; Lee, M.; Lee, B.J.; Lee, J.S. Activating $\mathrm{MoS}_{2}$ Basal Plane with $\mathrm{Ni}_{2} \mathrm{P}$ Nanoparticles for Pt-Like Hydrogen Evolution Reaction in Acidic Media. Adv. Funct. Mater. 2019, 29, 1809151. [CrossRef]

9. Gong, Q.; Wang, Y.; Hu, Q.; Zhou, J.; Feng, R.; Duchesne, P.N.; Zhang, P.; Chen, F.; Han, N.; Li, Y.; et al. Ultrasmall and phase-pure $\mathrm{W}_{2} \mathrm{C}$ nanoparticles for efficient electrocatalytic and photoelectrochemical hydrogen evolution. Nat. Commun. 2016, 7, 13216. [CrossRef]

10. Wu, H.B.; Xia, B.Y.; Yu, L.; Yu, X.Y.; Lou, X.W. Porous molybdenum carbide nano-octahedrons synthesized via confined carburization in metal-organic frameworks for efficient hydrogen production. Nat. Commun. 2015, 6, 6512. [CrossRef]

11. Zhu, J.; Hu, L.; Zhao, P.; Lee, L.Y.S.; Wong, K.Y. Recent Advances in Electrocatalytic Hydrogen Evolution Using Nanoparticles. Chem. Rev. 2020, 120, 851-918. [CrossRef]

12. Shin, Y.; Kim, S.E.; Kim, S. Thermal assessment of copper through silicon via in 3D IC. Microelectron. Eng. 2016, 156, 2-5. [CrossRef]

13. Hamidah, I.; Solehudin, A.; Hamdani, A.; Hasanah, L.; Khairurrijal, K.; Kurniawan, T.; Mamat, R.; Maryanti, R.; Nandiyanto, A.B.D.; Hammouti, B. Corrosion of copper alloys in $\mathrm{KOH}, \mathrm{NaOH}, \mathrm{NaCl}$, and $\mathrm{HCl}$ electrolyte solutions and its impact to the mechanical properties. Alex. Eng. J. 2021, 60, 2235-2243. [CrossRef]

14. Zhao, S.; Huang, J.; Liu, Y.; Shen, J.; Wang, H.; Yang, X.; Zhu, Y.; Li, C. Multimetallic Ni-Mo/Cu nanowires as nonprecious and efficient full water splitting catalyst. J. Mater. Chem. A 2017, 5, 4207-4214. [CrossRef]

15. Sivasakthi, P.; Sangaranarayanan, M.V.; Gurumallesh Prabu, H. Micro-nanoarchitectures of electrodeposited Ni-ITO nanocomposites on copper foil as electrocatalysts for the oxygen evolution reaction. New J. Chem. 2021, 45, 5146-5153. [CrossRef]

16. Li, C.; Zhang, B.; Li, Y.; Hao, S.; Cao, X.; Yang, G.; Wu, J.; Huang, Y. Self-assembled Cu-Ni bimetal oxide 3D in-plane epitaxial structures for highly efficient oxygen evolution reaction. Appl. Catal. B: Environ. 2019, 244, 56-62. [CrossRef]

17. Ngamlerdpokin, K.; Tantavichet, N. Electrodeposition of nickel-copper alloys to use as a cathode for hydrogen evolution in an alkaline media. Int. J. Hydrog. Energy 2014, 39, 2505-2515. [CrossRef]

18. Solmaz, R.; Döner, A.; Kardaş, G. Electrochemical deposition and characterization of NiCu coatings as cathode materials for hydrogen evolution reaction. Electrochem. Commun. 2008, 10, 1909-1911. [CrossRef] 
19. Solmaz, R.; Döner, A.; Kardaş, G. The stability of hydrogen evolution activity and corrosion behavior of NiCu coatings with long-term electrolysis in alkaline solution. Int. J. Hydrog. Energy 2009, 34, 2089-2094. [CrossRef]

20. Damian, A.; Omanovic, S. Ni and Ni-Mo hydrogen evolution electrocatalysts electrodeposited in a polyaniline matrix. J. Power Sources 2006, 158, 464-476. [CrossRef]

21. Gomez Vidales, A.; Omanovic, S. Evaluation of nickel-molybdenum-oxides as cathodes for hydrogen evolution by water electrolysis in acidic, alkaline, and neutral media. Electrochim. Acta 2018, 262, 115-123. [CrossRef]

22. Navarro-Flores, E.; Chong, Z.; Omanovic, S. Characterization of Ni, NiMo, NiW and NiFe electroactive coatings as electrocatalysts for hydrogen evolution in an acidic medium. J. Mol. Catal. A: Chem. 2005, 226, 179-197. [CrossRef]

23. Kawashima, A.; Akiyama, E.; Habazaki, H.; Hashimoto, K. Characterization of sputter-deposited Ni-Mo and Ni-W alloy electrocatalysts for hydrogen evolution in alkaline solution. Mater. Sci. Eng. A 1997, 226-228, 905-909. [CrossRef]

24. Highfield, J.G.; Claude, E.; Oguro, K. Electrocatalytic synergism in Ni/Mo cathodes for hydrogen evolution in acid medium: A new model. Electrochim. Acta 1999, 44, 2805-2814. [CrossRef]

25. Jakšić, J.M.; Vojnović, M.V.; Krstajić, N.V. Kinetic analysis of hydrogen evolution at Ni-Mo alloy electrodes. Electrochim. Acta 2000, 45, 4151-4158. [CrossRef]

26. Krstajić, N.V.; Gajić-Krstajić, L.; Lačnjevac, U.; Jović, B.M.; Mora, S.; Jović, V.D. Non-noble metal composite cathodes for hydrogen evolution. Part I: The $\mathrm{Ni}-\mathrm{MoO}_{\mathrm{x}}$ coatings electrodeposited from Watt's type bath containing $\mathrm{MoO}_{3}$ powder particles. Int. J. Hydrog. Energy 2011, 36, 6441-6449. [CrossRef]

27. Krstajić, N.V.; Lačnjevac, U.; Jović, B.M.; Mora, S.; Jović, V.D. Non-noble metal composite cathodes for hydrogen evolution. Part II: The $\mathrm{Ni}-\mathrm{MoO}_{2}$ coatings electrodeposited from nickel chloride-ammonium chloride bath containing $\mathrm{MoO}_{2}$ powder particles. Int J. Hydrog. Energy 2011, 36, 6450-6461. [CrossRef]

28. Harinipriya, S.; Sangaranarayanan, M.V. Influence of the work function on electron transfer processes at metals: Application to the hydrogen evolution reaction. Langmuir 2002, 18, 5572-5578. [CrossRef]

29. Tilak, B.V. High Performance Electrode Materials for the Hydrogen Evolution Reaction From Alkaline Media. Electrochem. Soc. Ext. Abstr. 1983, 97, 359-393. [CrossRef]

30. Mckone, J.R.; Sadtler, B.F.; Werlang, C.A.; Lewis, N.S.; Gray, H.B. Ni-Mo Nanopowders for Efficient Electrochemical Hydrogen Evolution. ACS Catal. 2013, 3, 166-169. [CrossRef]

31. Sharma, L.; Khushwaha, H.S.; Mathur, A.; Halder, A. Role of molybdenum in $\mathrm{Ni}-\mathrm{MoO}_{2}$ catalysts supported on reduced graphene oxide for temperature dependent hydrogen evolution reaction. J. Solid State Chem. 2018, 265, 208-217. [CrossRef]

32. Xu, Y.; Lai, K.; Gu, C.; Jiang, T.; Shen, X.; Zeng, S.; Ho, A.H.P.; Ang, D.S.; Zhou, J. Electrical Tuning of MoOx/Ag Hybrids and Investigation of their Surface-Enhanced Raman Scattering Performance. Phys. Status Solidi-Rapid Res. Lett. 2021, 15, 2000499. [CrossRef]

33. Crist, B. A Review of XPS Data-Banks. XPS Int. 2007, 1, 1-52.

34. Santosh, K.C.; Longo, R.C.; Addou, R.; Wallace, R.M.; Cho, K. Electronic properties of $\mathrm{MoS}_{2} / \mathrm{MoO}_{\mathrm{x}}$ interfaces: Implications in Tunnel Field Effect Transistors and Hole Contacts. Sci. Rep. 2016, 6, 33562. [CrossRef]

35. Chen, M.; Friend, C.M.; Kaxiras, E. The chemical nature of surface point defects on $\mathrm{MoO}_{3}(010)$ : Adsorption of hydrogen and methyl. J. Am. Chem. Soc. 2001, 123, 2224-2230. [CrossRef]

36. Sun, Y.; Gao, S.; Lei, F.; Xie, Y. Atomically-thin two-dimensional sheets for understanding active sites in catalysis. Chem. Soc. Rev. 2015, 44, 623-636. [CrossRef]

37. Kim, H.S.; Cook, J.B.; Lin, H.; Ko, J.S.; Tolbert, S.H.; Ozolins, V.; Dunn, B. Oxygen vacancies enhance pseudocapacitive charge storage properties of $\mathrm{MoO}_{3-\mathrm{x}}$. Nat. Mater. 2017, 16, 454-462. [CrossRef]

38. Zhuiykov, S.; Kats, E.; Carey, B.; Balendhran, S. Proton intercalated two-dimensional $\mathrm{WO}_{3}$ nano-flakes with enhanced chargecarrier mobility at room temperature. Nanoscale 2014, 6, 15029-15036. [CrossRef]

39. Liang, H.; Li, L.; Meng, F.; Dang, L.; Zhuo, J.; Forticaux, A.; Wang, Z.; Jin, S. Porous Two-Dimensional Nanosheets Converted from Layered Double Hydroxides and Their Applications in Electrocatalytic Water Splitting. Chem. Mater. 2015, 27, 5702-5711. [CrossRef]

40. Wang, J.; Zhong, H.X.; Wang, Z.L.; Meng, F.L.; Zhang, X.B. Integrated Three-Dimensional Carbon Paper/Carbon Tubes/CobaltSulfide Sheets as an Efficient Electrode for Overall Water Splitting. ACS Nano 2016, 10, 2342-2348. [CrossRef]

41. Zheng, Y.; Jiao, Y.; Li, L.H.; Xing, T.; Chen, Y.; Jaroniec, M.; Qiao, S.Z. Toward design of synergistically active carbon-based catalysts for electrocatalytic hydrogen evolution. ACS Nano 2014, 8, 5290-5296. [CrossRef]

42. Wang, L.; Lee, C.Y.; Schmuki, P. Solar water splitting: Preserving the beneficial small feature size in porous $\alpha$-Fe $\mathrm{O}_{3}$ photoelectrodes during annealing. J. Mater. Chem. A 2013, 1, 212-215. [CrossRef] 